\title{
Desain dan Analisa Sistem Suspensi Mobil Multiguna Pedesaan Menggunakan Peredam Magnetorheological Dengan Standar Kenyamanan ISO 2631
}

\author{
Fridam Amruloh Baqarizky dan I Nyoman Sutantra \\ Departemen Teknik Mesin, Fakultas Teknologi Industri, Institut Teknologi Sepuluh Nopember (ITS) \\ e-mail:tantra@me.its.ac.id
}

\begin{abstract}
Abstrak-Mobil multiguna pedesaan merupakan sebuah kendaraan yang dirancang untuk meningkatkan produktifitas masyarakat pedesaan. Mobil ini dikatakan multiguna dikarenakan box pada bagian belakang dapat diganti sesuai dengan angkutan yang dibawa yaitu manusia atau perlatan pedesaan. Untuk menjaga kenyamanan penumpang dan peralatan pedesaan diperlukan sistem suspensi yang baik. Penggunaan sistem suspensi dengan peredam magnetorheological merupakan salah satu caranya, karena pada sistem ini nilai konstanta redaman dapat berubah sesuai dengan profil permukaan jalan. Untuk merancang sistem suspensi tersebut terdapat dua macam tahapan, yaitu tahap perancangan dan analisa. Pada tahap perancangan dilakukan perhitungan dan simulasi untuk mendapatkan nilai konstanta pegas suspensi dan arus yang masuk kedalam peredam. Pada tahap analisa, dilakukan analisa kenyamanan yang dihasilkan sistem suspensi yang sudah dirancang dengan menggunakan beberapa standar kenyamanan dan keamanan seperti ISO 2631, Assesment Diagram for Vibration, Beissbarth Automotive Group. Hasil yang didapatkan pada studi ini adalah nilai kekakuan pegas suspensi depan $(\mathrm{Ksf})=\mathbf{5 6 9 0 4 , 5 7 5 4 1} \mathrm{N} / \mathrm{m}$, kekakuan pegas belakang $(\mathrm{Ksr})=70864,50183 \mathrm{~N} / \mathrm{m}$. Dan analisa menunjukkan dengan menggunakan dengan menggunakan standar kenyamanan dan kemanan diatas, suspensi hasil rancangan memiliki tingkat keamanan dan kenyamanan yang baik.
\end{abstract}

Kata Kunci-Peredam magnetorheological, keamanan, Beissbarth Automotive Group, kenyamanan, ISO 2631, Assesment Diagram for Vibration.

\section{PENDAHULUAN}

$\mathrm{P}$ ERTUMBUHAN industri otomotif di dunia membuat banyak perusahaan yang bergerak dalam bidang otomotif berlomba-lomba untuk menciptakan kendaraan dengan tujuan akhir zero fossil fuel, zero energy loss, zero emission, zero accident, zero congestion. Selain itu, salah satu faktor yang penting lainnya pada kendaraan adalah kenyamanan. Dimana salah satu hal yang berpengaruh pada kenyaman kendaraan adalah sistem suspensi. Sistem suspens yang ada saat ini dibagi menjadi 3, yaitu sistem suspensi pasif, semi aktif, dan aktif. Sistem suspensi yang umum digunakan pada kendaraan sampai saat ini adalah sistem suspensi pasif, dimana sistem suspensi pasif memiliki besar kekakuan pegas dan konstanta redaman yang bernilai konstan. Namun, pada akhir-akhir ini dikembangkan teknologi yang dapat mengendalikan getaran secara aktif pada sprung mass agar kenyamanan dapat terkendali pada setiap kondisi jalan, yaitu sistem suspensi semi aktif dan aktif. Dimana perbedaan antara sistem suspensi semi aktif dan suspensi aktif adalah untuk suspensi semi aktif hanya nilai peredamnya saja yang berubah sesuai profil jalan, sementara untuk suspensi aktif niali kekakuan pegas dan konstanta redaman dapat berubah ubah sesuai profil jalan. Dimana setiap jenis suspensi memiliki kelebihan dan kelemahan masing masing dari segi struktur, biaya, kenyamanan, handling, reability.

Pada penelitian sebelumnya tentang desain dan analisa sistem suspensi mobil produksi multiguna pedesaan dengan standar kenyamanan ISO 2631 dimana penelitian tersebut bertujuan untuk mendapatkan nilai kekakuan pegas suspensi dan konstanta redaman suspensi untuk mobil multiguna pedesaan, dengan sistem suspensi pasif [1]. Kemudian penelitian lainnya tentang permodelan dan studi karakteristik sistem suspensi semi-aktif dengan peredam magnetorheological berisikan perbandingan antara tiga jenis suspensi semi-aktif dengan peredam magnetorheological yaitu Metode Parametrik (Spencer, Bouc-Wen), Model Non Parametrik, yang dibandingkan dengan suspensi pasif [2].

Pada penelitian ini merupakan kelanjutan dari kedua penelitian sebelumnya. Yaitu akan dirancang sistem suspensi pada mobil multiguna pedesaan menggunakan peredam magnetorheological. Dimana sistem suspensi dengan peredam magnetorheological adalah sistem suspensi yang memanfaatkan arus listrik untuk memperbesar gaya redam. Dengan menggunakan pemodelan dari peredam magnetorheological dan kendaraan half car, didapatkan nilai kekakuan pegas dengan damper magnetorheological. Sehingga, dari dapat dianalisa respon kenyamanan dan keamanan akibat penggunaan peredam magnetorheological pada sistem suspensi mobil multiguna pedesaan.

\section{URAIAN PENELITIAN}

Penelitian ini diawali pengumpulan data dan pemodelan mobil multiguna pedesaan dengan model setengah kendaraan. Langkah selanjutnya adalah melakukan perancangan sistem suspensi (pegas dan redaman), dan menganalisanyadengan menggunakan standar kenyamanan dan keamanan.

\section{A. Pegas Sistem Suspensi}

Sebuah pegas didefinisikan sebagai suatu benda elastis (elastic body). Sebuah pegas akan berubah bentuk apabila diberi beban dan kembali lagi ke bentuk awal apabila beban yang diberikan dilepaskan. Dimana pegas memiliki beberapa perananan penting yaitu sebagai bantalan yang menyerap dan mengontrol energy ketika terjadi getaran. sebagai penahan dan pengukur gaya, sebagai pengontol gerakan dengan cara mempertahankan kontak antara 2 elemen, seperti pada cams dan followers. Dan sebagai penyimpan energi. Pegas memiliki banyak jenis seperti pegas daun, pegas puntir, pegas ulir. Dimana yang digunakan pada penelitian kali ini untuk suspensi depan dan belakang adalah pegas ulir. 
Spring Rate $(k)$ atau konstanta kekakuan pegas adalah beban yang diperlukan per unit defleksi dari pegas. Secara matematis dirumuskan sebagai berikut.

$k=W / \delta$

dimana $W$ adalah beban total, $\delta$ adalah defleksi dari pegas. Untuk beban yang diperhitungkan pada penelitian ini digunakan perhitungan beban statis dan dinamis. Dimana dari kedua jenis beban tersebut akan dipilih beban paling besar untuk digunakan pada perhitungan kekakuan pegas. Persamaan beban dinamis dan statis dirumuskan sebagai berikut.

\section{Beban Statis}

$$
\begin{aligned}
& W f=\frac{L_{r}}{L} W \\
& W r=\frac{L_{f}}{L} W
\end{aligned}
$$

\section{Beban Dinamis Diperlambat}

$$
\begin{aligned}
& W_{f}=\frac{1}{L}\left[W L_{r}+h\left(\frac{W}{g} a-\frac{1}{2} \rho C_{d} A_{f} V^{2}\right)\right] \\
& W_{r}=\frac{1}{L}\left[W L_{f}+h\left(\frac{1}{2} \rho C_{d} A_{f} V^{2}-\frac{W}{g} a\right)\right]
\end{aligned}
$$

\section{Beban Dinamis Dipercepat}

$$
\begin{aligned}
& W_{f}=\frac{1}{L}\left[W L_{r}-h\left(\frac{W}{g} a+\frac{1}{2} \rho C_{d} A_{f} V^{2}\right)\right] \\
& W_{r}=\frac{1}{L}\left[W L_{f}+h\left(\frac{W}{g} a+\frac{1}{2} \rho C_{d} A_{f} V^{2}\right)\right]
\end{aligned}
$$

dimana $W_{f}$ adalah distribusi beban pada ban depan, $W_{r}$ adalah distribusi beban pada ban belakang, $W$ adalah beban total, $L_{f}$ adalah jarak sumbu roda depan ke center of gravity, $L_{r}$ adalah jarak sumbu belakang ke center of gravity, $L$ adalah panjang wheelbase, $h$ adalah tinggi center of gravity ke permukaan tanah, $g$ adalah konstanta gravitasi, $\rho$ adalah massa jenis udara, $C_{d}$ adalah koofiesien $d r a g, A_{f}$ adalah luas frontal kendaraan, $V$ adalah kecepatan relaif kendaraan.

\section{B. Peredam Magnetorheological}

Peredam magnetorheological menggunakan partikel magnetik sebagai pengganti cairan yang digunakan pada peredam pasif. Dengan menggunakan prinsip medan magnet cairan magnetik ini dapat merubah viskositasnya. Fluida peredam ini berisi cairan peredam pasif standar sebesar 20$40 \%$, partikel besi dengan ukuran 3-10 mikron.

Prinsip kerja dari peredam ini adalah ketika tidak ada medan magnet (arus masuk), cairan ini akan bersifat seperti cairan newtonian yang dapat bergerak bebas. Namun, ketika sebuah medan magnet diterapkan partikel besi akan bertindak sebagai dipol yang akan membentuk pola yang selaras sepanjang garis fluks. Fenomena ini hanya terjadi pada wilayah medan magnet saja, diluar itu cairan yang lain bergerak bebas namun terbatas. Hal tersebut menyebabkan gaya redaman semakin membesar.

Peredam magnetorheological dapat dimodelkan menjadi beberapa pemodelan, dianataranya adalah parametrik (boucwen, spencer), dan non parametrik. Pada metode parametrik, peredam dikarakteristikkan sebagai sistem dengan elemen linear mauupun non linear, yang didefenisikan dengan parameter spring, dashspot (peredam viscous) dan elemen mekanik lainnya. Dimana model spencer hanya pengembangan dari model bouc-wen. Sementara, untuk non parametrik peredam dimodelkan dengan fungsi khusus sebagai polinomial, tangen hiperbolik, delay, offset atau dapat dimodelkan dengan metode kecerdasan buatan (logika fuzzy). Pada penelitian kali ini digunakan model bouc-wen yaitu seperti pada gambar 1 .

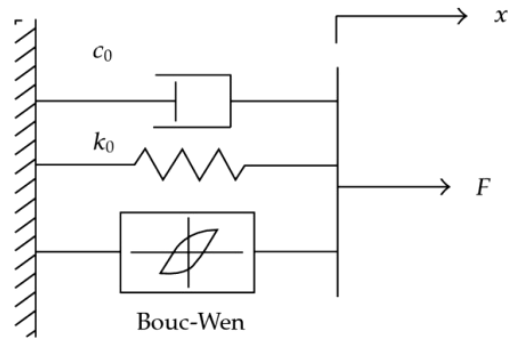

Gambar 1. Struktur Model Bouc-Wen [3]

dimana model Bouc-Wen memiliki persamaan gaya redam yang dirumuskan sebagai berikut.

$$
F=C_{o} x_{d}+k_{o} x_{d}+\alpha z
$$

dimana variabel z dirumuskan sebagai

$$
\dot{z}=-\gamma\left|\dot{x}_{d}\right| z|z|^{n-1}-\beta \dot{x}_{d}|z|^{n}+A \dot{x}_{d}
$$

untuk metdode parametrik berlaku beberapa persamaan yaitu sebagai berikut.

$$
\begin{aligned}
& \alpha=\alpha_{a}+\left(\alpha_{b} u\right) \\
& c_{1}=c_{1 a}+\left(c_{1 b} u\right) \\
& c_{0}=c_{0 a}+\left(c_{0 b} u\right) \\
& \dot{u}=-\eta(u-v)
\end{aligned}
$$

dimana $\gamma, \beta, A$ adalah parameter kontrol linear sebelum pembebanan, $\alpha$ adalah parameter kekakuan gaya redaman, $k_{o}$ adalah kekakuan pegas, $c_{o}$ adalah peredam viscous, $n$ adalah parameter yang menyatakan kehalusan transisi karakter peredam, dan $\eta$ adalah filter waktu.

\section{Pemdodelan Getaran Kendaraan}

Analisa getaran yang terjadi pada kendaraan untuk melihhat karakteristik getaran dapat dilakukan dengan cara pemodelan getaran kendaraan. Pemodelan dinamis kendaraan terdiri dari beberapa jenis sesuai dengan kebutuhannya, diantaranya adalah model seperempat kendaraan, setengah kendaraan dan full kendaraan. Pemodelan dinamis kendaraan dipilih sesuai dengan kebutuhan analisa getaran kendaraan.

Pada penelitian ini digunakan model setengah kendaraan yang ditunjukkan pada gambar 2 untuk menganalisa respon getaran kendaraan. Selanjutnya, dilakukan analisa gaya-gaya yang berkerja pada massa yang ditinjau (degree of freedom). Sehingga, dengan melakukan penyederhanaan sesuai dengan hukum Newton kedua, maka akan didapat persamaan matematis sistem gerak suspensi kendaraan seperti berikut. 


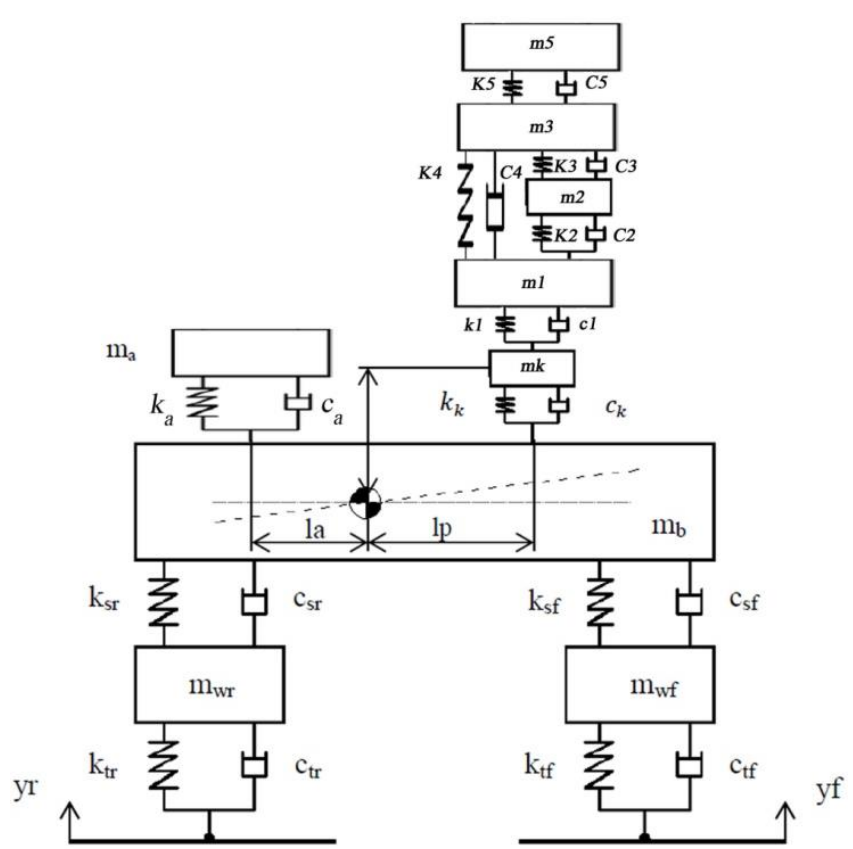

Gambar 2. Pemodelan Getaran Setengah Kendaraan

dari free body diagram diatas dapat ditulis persamaan gerak sebagai berikut :

Persamaan gerak unsprung mass depan $\left(\mathrm{m}_{\mathrm{wf}}\right)$ :

$$
\begin{aligned}
& m_{w f} \ddot{\mathrm{x}}_{w f}+\left[\left(c_{t f}+c_{s f}\right) \dot{\mathrm{x}}_{w f}\right]-c_{t f} \dot{\mathrm{y}}_{f}-c_{s f} \dot{\mathrm{x}}- \\
& c_{s f} \dot{\theta} l f+\left[\left(k_{t f}+k_{s f}\right) x_{w f}\right]-k_{t f} y_{f}-k_{s f} x- \\
& k_{s f} \theta l f=0
\end{aligned}
$$

Persamaan gerak unsprung mass belakang $\left(\mathrm{m}_{\mathrm{wr}}\right)$ :

$$
\begin{gathered}
m_{w r} \ddot{\mathrm{x}}_{w r}+c_{t r} \dot{\mathrm{x}}_{w r}-c_{t r} \dot{\mathrm{y}}_{r}+F d_{r}+\left[\left(k_{t r}+\right.\right. \\
\left.\left.k_{s r}\right) \quad x_{w r}\right]-k_{t r} y_{r}-k_{s r} x-k_{s r} \theta l r=0
\end{gathered}
$$

Persamaan gerak massa bodi kendaraan $\left(\mathrm{m}_{\mathrm{b}}\right)$ :

$$
\begin{aligned}
& m_{b} \ddot{\mathrm{x}}+F_{d f}+F_{d r}+\left[\left(k_{s r}+k_{s f}\right) x\right]+\left[\left(k_{s f} l f-\right.\right. \\
& \left.\left.k_{s r} l r\right) \theta\right]-k_{s r} x_{w r}-k_{s f} x_{w f}+k_{k} x+k_{k} l p \theta- \\
& k_{k} x_{k}+c_{k} \dot{\mathrm{x}}+c_{k} l p \dot{\theta}-c_{k} \dot{\mathrm{x}}_{k}+k_{a} x+k_{a} l a \theta- \\
& k_{a} x_{a}+c_{a} \dot{\mathrm{x}}+c_{a} l a \dot{\theta}-c_{a} \dot{\mathrm{x}}_{a}=0
\end{aligned}
$$

$$
\begin{aligned}
& \quad I_{b} \ddot{\theta}-F_{d f} l f+F_{d r} l r+\left[\left(-k_{s r}+k_{s f} l f\right) x\right]+ \\
& {\left[\left(k_{s f} l f^{2}+k_{s r} l r^{2}\right) \theta\right]+k_{s r} l r x_{w r}-k_{s f} l f x_{w f}+} \\
& k_{k} l p x+k_{k} l p^{2} \theta-k_{k} l p x_{k}+c_{k} l p \dot{\mathrm{x}}+c_{k} l p^{2} \dot{\theta}- \\
& c_{k} l p \dot{\mathrm{x}}_{k}+k_{a} l a x+k_{a} l a^{2} \theta-k_{a} l a x_{a}+c_{a} l a \dot{\mathrm{x}}+ \\
& l a^{2} \dot{\theta}-c_{a} l a \dot{\mathrm{x}}_{a}= \\
& 0
\end{aligned}
$$

Persamaan gerak massa alat yang dibawa $\left(\mathrm{m}_{\mathrm{a}}\right)$ :

$$
m_{a} \ddot{\mathrm{x}}_{a}-k_{a}\left(x+l a \theta-x_{a}\right)-c_{a}\left(\dot{\mathrm{x}}+l a \dot{\theta}-\dot{\mathrm{x}}_{a}\right)=0
$$

Persamaan gerak massa kursi pengemudi kendaraan $\left(\mathrm{m}_{\mathrm{k}}\right)$ : $m_{k} \ddot{\mathrm{x}}_{k}+\left[\left(k_{k}+k_{1}\right) x_{k}\right]+\left[\left(c_{k}+c_{1}\right) \dot{\mathrm{x}}_{k}\right]-k_{1} x_{1}-$ $c_{1} \dot{\mathrm{x}}_{1}-k_{k} x-c_{k} \dot{\mathrm{x}}-k_{k} \operatorname{lp} \theta-$ $c_{k} l p \theta \doteq 0$

Persamaan gerak massa lower torso $\left(\mathrm{m}_{1}\right)$ :

$$
\begin{aligned}
& m_{1} \ddot{\mathrm{x}}_{1}+\left[\left(k_{1}+k_{4}+k_{2}\right) x_{1}\right]+\left[\left(c_{1}+c_{4}+\right.\right. \\
& \left.\left.c_{2}\right) \dot{\mathrm{x}}_{1}\right]-k_{1} x_{k}-c_{1} \dot{\mathrm{x}}_{k}-k_{4} x_{3}-c_{4} \dot{\mathrm{x}}_{3}-k_{2} x_{2}- \\
& c_{2} \dot{\mathrm{x}}_{2}=0
\end{aligned}
$$

Persamaan gerak massa viscera $\left(\mathrm{m}_{2}\right)$ :

$m_{2} \ddot{\mathrm{x}}_{2}+\left[\left(k_{2}+k_{3}\right) x_{2}\right]+\left[\left(c_{2}+c_{3}\right) \dot{\mathrm{x}}_{2}\right]-k_{2} x_{1}-$ $c_{2} \dot{\mathrm{x}}_{1}-k_{3} x_{3}-c_{3} \dot{\mathrm{x}}_{3}=0$

Persamaan gerak massa upper torso $\left(\mathrm{m}_{3}\right)$ :

$m_{3} \ddot{\mathrm{x}}_{3}+\left[\left(k_{4}+k_{3}+k_{5}\right) x_{3}\right]+\left[\left(c_{4}+c_{3}+\right.\right.$

$\left.\left.c_{5}\right) \dot{\mathrm{x}}_{3}\right]-k_{4} x_{1}-c_{4} \dot{\mathrm{x}}_{1}-k_{3} x_{2}-c_{3} \dot{\mathrm{x}}_{2}-k_{5} x_{5}-$

$c_{5} \dot{\mathrm{x}}_{5}=0$

Persamaan gerak massa head and neck $\left(\mathrm{m}_{5}\right)$ :

$m_{5} \ddot{\mathrm{x}}_{5}+k_{5} x_{5}+c_{5} \dot{\mathrm{x}}_{5}-k_{5} x_{3}-c_{5} \dot{\mathrm{x}}_{3}=0$

dimana $m_{w f}$ adalah massa ban depan, $m_{w r}$ adalah massa ban belakang, $m_{b}$ adalah massa bodi kendaraan, $m_{a}$ massa alat, $m_{k}$ adalah massa kursi, $m_{1}$ massa lower torso, $m_{2}$ adalah massa viscera, $m_{3}$ adalah massa upper torso, $m_{5}$ adalah massa head \& neck., $\dot{\mathrm{y}}_{f}, y_{f}$ adalah kecepatan permukaan jalan, defleksi jalan, $\ddot{\mathrm{x}}_{w f}, \dot{\mathrm{x}}_{w f}, x_{w f}$ adalah percepatan ban depan, kecepatan ban depan dan defleksi ban depan. $\ddot{\mathrm{x}}_{w r}, \dot{\mathrm{x}}_{w r}, x_{w r}$ adalah percepatan ban belakang, kecepatan ban belakang dan defleksi ban belakang. $\ddot{x}, \dot{\mathrm{x}}, x$ adalah percepatan bodi, kecepatan bodi dan defleksi bodi. $\ddot{\theta}, \dot{\theta}, \theta$ adalah percepatan sudut bodi, kecepatan sudut bodi, dan sudut posisi bodi. $\ddot{\mathrm{x}}_{1}, \dot{\mathrm{x}}_{1}, x_{1}$ adalah percepatan lower torso, kecepatan lower torso dan defleksi lower torso. $\ddot{\mathrm{x}}_{k}, \dot{\mathrm{x}}_{k}, x_{k}$ adalah percepatan kursi, kecepatan kursi dan defleksi kursi.

$\ddot{\mathrm{x}}_{2}, \dot{\mathrm{x}}_{2}, x_{2}$ adalah percepatan viscera, kecepatan viscera dan defleksi viscera. $\ddot{\mathrm{x}}_{3}, \dot{\mathrm{x}}_{3}, x_{3}$ adalah percepatan upper torso, kecepatan upper torso dan defleksi upper torso. $\ddot{\mathrm{x}}_{5}, \dot{\mathrm{x}}_{5}, x_{5}$ adalah percepatan head \& neck, kecepatan head \& neck dan defleksi head \& neck. $c_{t f}, k_{t f}$ adalah konstanta redaman dan pegas ban depan. $c_{t r}, k_{t r}$ adalah konstanta redaman dan pegas ban belakang. $c_{s f}, k_{s f}$ adalah konstanta redaman dan pegas suspensi depan. $c_{s r}, k_{s r}$ adalah konstanta redaman dan pegas suspensi belakang. $c_{a}, k_{a}$ adalah konstanta redaman dan pegas alat. $c_{k}, k_{k}$ adalah konstanta redaman dan pegas kursi. $c_{1}, k_{1}$ adalah konstanta redaman dan pegas lower torso. $c_{2}, k_{2}$ adalah konstanta redaman dan pegas viscera. $c_{3}, k_{3}$ adalah konstanta redaman dan pegas upper torso. $c_{4}, k_{4}$ adalah konstanta redaman dan pegas antara lower torso dan upper torso. $c_{5}, k_{5}$ adalah konstanta redaman dan pegas anatar head \& neck. If adalah jarak sumbu roda depan ke center of gravity. Ir 
adalah jarak sumbu roda belakang ke center of gravity. Ip adalah jarak penumpang ke center of gravity. la adalah jarak penumpang ke center of gravity.

\section{HASIL DAN ANALISIS}

\section{A. Perancangan Pegas Sistem Suspensi}

Berdasarkan spesifikasi mobil multiguna pedesaan yang ditunjukkan pada tabel 3 di lampiran. Dengan mendapatkan perubahan center of gravity akibat adanya perubahan muatan, maka dengan menggunakan persamaan (2) - (7) didapatkan nilai beban maksimal yang diterima kendaraan yang ditunjukkan pada tabel 4 pada lampiran. Dari tabel 4 dipilih beban maksimal yaitu pada $W_{f}$ dinamis diperlambat dan $W_{r}$ dinamis dipercepat. Sehingga, dengan menggunakan persamaan (1) didapatkan nilai kekakuan pegas depan dan belakang yang ditunjukkan pada tabel 1 .

Tabel 1.

Perhitungan Nilai Kekakuan Pegas

\begin{tabular}{|c|r|}
\hline \multicolumn{2}{|c|}{ Perhitungan Pegas Suspensi } \\
\hline Wf Max(N) & $\mathbf{5 6 9 0 , 4 5 7 5 4 1}$ \\
\hline Wr Max(N) & $\mathbf{8 5 0 3 , 7 4 0 2 1 9}$ \\
\hline Defleksi Maksimal Depan(m) & $\mathbf{0 , 1}$ \\
\hline Defleksi Maksimal Belakang(m) & $\mathbf{0 , 1 2}$ \\
\hline $\mathrm{Ksf}(\mathrm{N} / \mathrm{m})$ & 56904,57541 \\
\hline $\mathrm{Ksr}(\mathrm{N} / \mathrm{m})$ & 70864,50183 \\
\hline
\end{tabular}

\section{B. Perancangan Redaman Sistem Suspensi}

Untuk mencari nilai konstanta redaman suspensi perlu diketahui besar arus yang masuk ke dalam redaman., untuk mengetahuinya digunakan simulasi dengan pemodelan setengah kendaraan. Dimana nilai konstanta redaman dipilih dengan memvariasikan nilai arus yang masuk kedalam sistem suspensi. Parameter utama untuk pemilihan konstanta redaman dipilih dari sisi kenyamanan.

Untuk pemodelan redaman magnetorheological pada penelitian ini digunakan pemodelan Bouce-Wen. Dimana pemodelan Bouce-Wen memiliki parameter-parameter yang ditunjukkan pada tabel 2 pada lampiran. Dengan menggunakan pemodelan setengah kendaraan dan peredam magnetorheological dengan model bouc-wen pada simulasi dengan software. Didapatkan respon getaran terhadap kenyamanan dan keamanan kendaraan yang ditunjukkan pada gambar 2

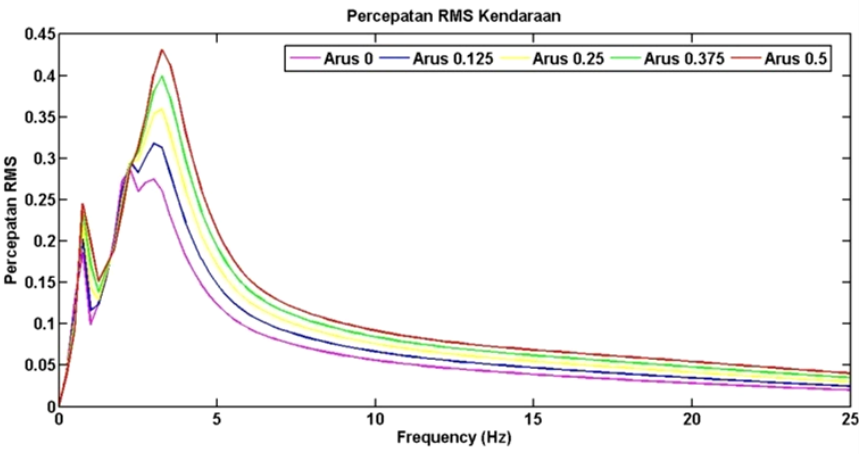

Gambar 5. Pengaruh Variasi Arus Terhadap Percepatan RMS Pengemudi.

Pada respon percepatan RMS bodi yang ditunjukkan gambar 5 menunjukkan bahwa semakin besar arus yang masuk ke dalam sistem suspensi maka semakin besar juga nilai percepatan arah vertikal yang diterima oleh bodi kendaraan, sehingga menyebabkan tingkat kenyamanan yang diterima pengemudi maupun penumpang akan semakin menurun. Sehingga, berdasarkan parameter diatas, yaitu RMS bodi kendaraan, dipilih arus untuk range $0 \mathrm{~A}$, sampai 0,25 A. Dikarenakan dengan arus tersebut dapat menghasilkan percepatan RMS bodi kendaraan yang kecil di bandingkan dengan 2 arus lainnya.

\section{Analisa Kenyamanan Suspensi Pada Pengemudi, Penumpang, dan Alat}

Untuk menganalisa kenyamanan pengemudi akan dilihat dari percepatan RMS pada setiap bagian tubuh yaitu head \& neck, upper torso, viscera, lowe torso. Menggunakan input jalan sinusoidal dengan amplitudo sebesar $0.05 \mathrm{~m}$ dan panjang gelombang sebesar $1 \mathrm{~m}$. Didapatkan hasil simulasi yang ditunjukkan pada gambar 6 dan 7. Dan untuk respon kenyamanan penumpang dan alat ditunjukkan pada gambar 8 dan 9.

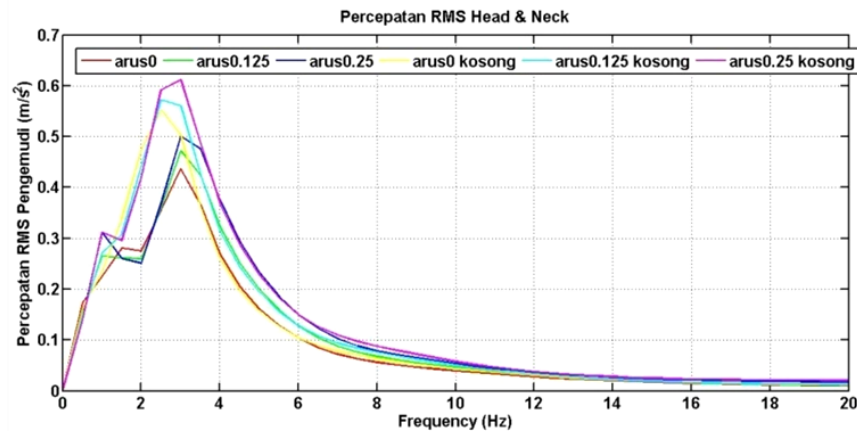

(a)

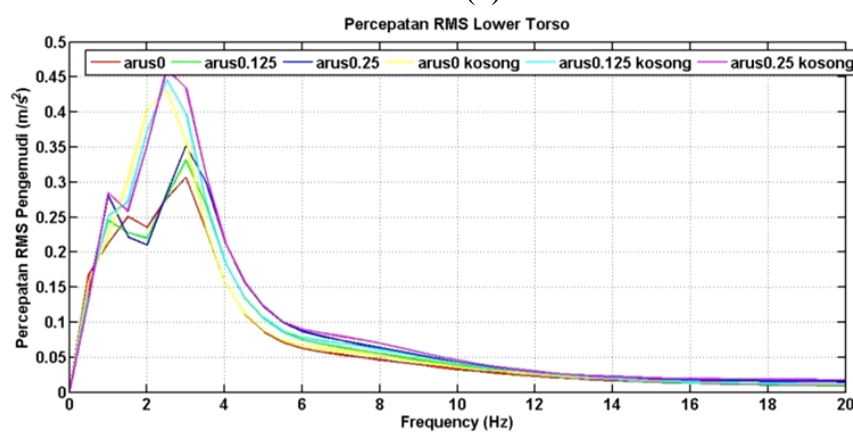

(b)

Gambar 6. Percepatan RMS terhadap Frekuensi Mobil Penumpang pada (a) Head \& Neck Pengemudi (b). Lower Torso Pengemudi.

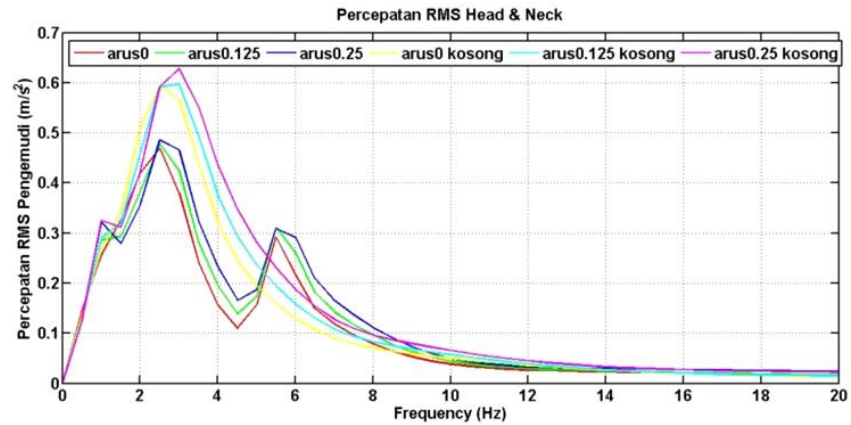

(a) 


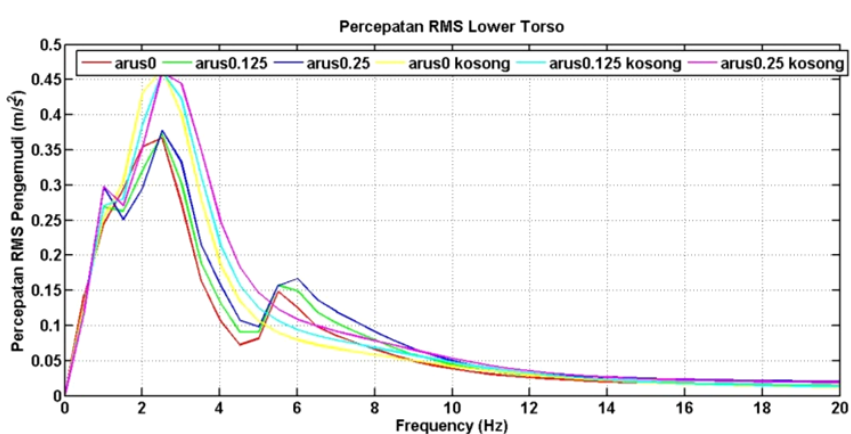

(b)

Gambar 7. Percepatan RMS terhadap Frekuensi Mobil Alat pada (a). Head \& Neck Pengemudi (b). Lower Torso Pengemudi.

Dari simulasi pada gambar 6 - 9 terlihat bahwa semakin besar arus yang masuk ke dalam sistem suspensi menyebabkan nilai percepatan RMS untuk penumpang, alat dan setiap bagian tubuh pengemudi semakin meningkat. Dengan meningkatnya nilai percepatan RMS maka akan menurunkan tingkat kenyamanan pengemudi, penumpang dan alat. Begitu pula untuk kendaraan kosong, namun pada kendaraan kosong perubahan tingkat kenyamanannya lebih besar untuk setiap kenaikan arus dibandingkan dengan kendaraan penuh.

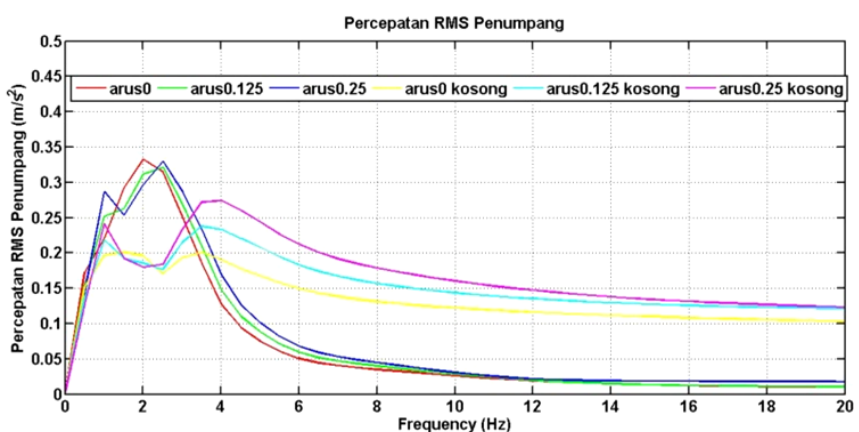

Gambar 8. Percepatan RMS terhadap Frekuensi Mobil Penumpang pada Penumpang

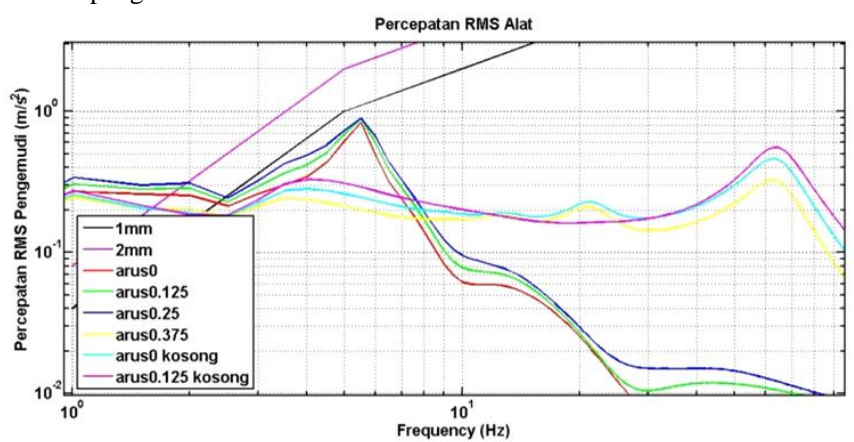

Gambar 9. Percepatan RMS terhadap Frekuensi pada Alat

Pada penelitian ini bagian tubuh yang dibahas hanya pada bagian head \& neck dan lower torso saja, dikarenakan pada bagian tubuh tersebut terjadi penurunan tingkat kenyamanan yang cukup signifikan. Berdasarkan literatur [4] untuk bagian head \& neck memiliki tingkat sensitivitas pada frekuensi 25 $\mathrm{Hz}$, sementara dari hasil simulasi yang didapatkan untuk bagian head \& neck pada konfigurasi mobil penumpang memiliki tingkat sensitivitas pada range frekuensi $2-4 \mathrm{~Hz}$, sementara untuk konfigurasi mobil alat memiliki tingkat sensitivitas pada $2-8 \mathrm{~Hz}$. Dan untuk bagian lower torso dari literatur didapatkan memiliki sensitivitas pada frekuensi 2 $20 \mathrm{~Hz}$, sementara untuk dari hasil simulasi untuk bagian lower torso pada konfigurasi mobil penumpang didapatkan sensitivitas pada frekuensi 2-4 Hz. Sementara, untuk konfigurasi mobil alat memiliki tingkat sensitivitas pada $2-$ $8 \mathrm{~Hz}$. Terjadi perbedaan yang sangat signifikan antara literatur dan simulasi pada bagian head \& neck dimana hal tersebut terjadi dikarenakan pada penelitian ini hanya memperhatikan ke arah vertikal saja, sementara sensitivitas sangat diperngaruhi oleh 2 hal yaitu frekuensi dan arah getaran. Untuk penumpang, berdasarkan literatur untuk seluruh tubuh manusia rata rata memiliki tingkat sensitivitas pada frekuensi 4 - $8 \mathrm{~Hz}$, sementara dari hasil simulasi yang didapatkan untuk seluruh tubuh penumpang memiliki tingkat sensitivitas pada range frekuensi $2-8 \mathrm{~Hz}$. Dari hasil diatas dapat dikatakan bahwa hasil simulasi sudah sesuai dengan standar yang ada.

Sehingga, dapat disimpulkan nilai konstanta pegas dan arus redaman yang digunakan sudah sesuai untuk digunakan, karena percepatan RMS yang didapatkan untuk alat berada dibawah displacement $1 \mathrm{~mm}$ dan masuk kedalam kondisi recommended. Begitu pula untuk setiap anggota tubuh dan penumpang dapat dikatakan pada kondisi nyaman karena percepatan RMS yang didapatkan setiap anggota tubuh dan penumpang termasuk kedalam kriteria tidak ada keluhan atau nilai percepatan RMS $<0,315 \mathrm{~m} / \mathrm{s}^{2}$.

\section{Analisa Kinerja Suspensi}

1) Rasio Redaman Suspensi

Untuk kecepatan $60 \mathrm{~km} / \mathrm{h}$ pada arus $0 \mathrm{~A}$ di dapat nilai nilai gaya redaman rata-rata sebesar 158,8931 $\mathrm{N}$ dengan nilai kecepatan relatif sebesar $0,0365 \mathrm{~m} / \mathrm{s}$. Untuk mendapat konstanta peredam didapatkan dengan membagi gaya redam dengan kecepatan relatif. Sehingga didapatkan nilai konstanta redaman sebesar 5266,67 N.s/m yang memiliki rasio redaman dengan cara membagi dengan criticalsebesar 0,41. Begitu pula untuk setiap arus lainnya, sehingga pada arus $0,125 \mathrm{~A}$ didapat rasio redaman sebesar 0,55. Pada arus 0,25 A didapat sebesar 0,9. Pada suspensi pasif rasio redaman sebesar 0,45.

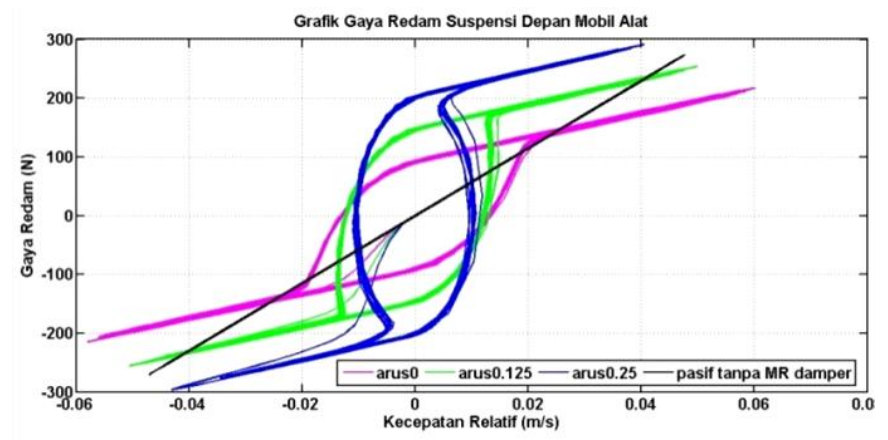

Gambar 10. Gaya Redaman Suspensi terhadap Kecepatan Relatif

\section{2) Defeleksi Suspensi}

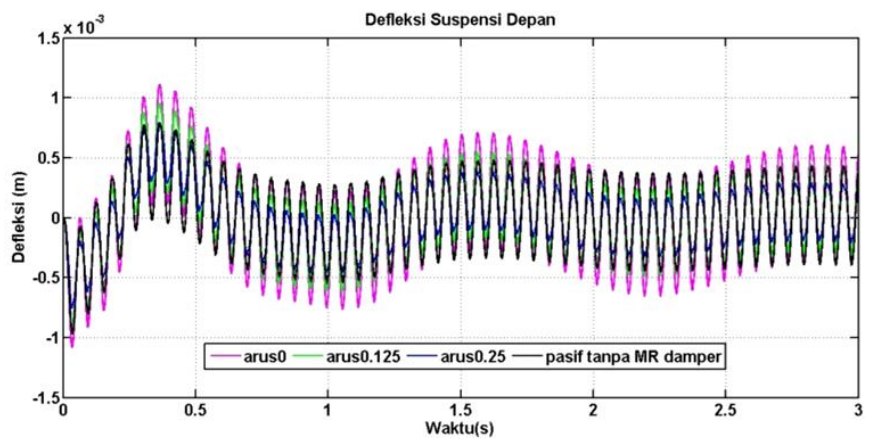

Gambar 11. Defleksi Suspensi terhadap Waktu 
Dari simulasi di atas terlihat bahwa jenis sistem suspensi sangat berpengaruh terhadap defleksi maksimal suspensi. Semakin besar rasio redaman maka nilai defleksi akan semakin kecil. Pada gambar 11 menunjukkan hasil simulasi defleksi suspensi depan mobil menggunakan sistem suspensi semi aktif dengan arus $0 \mathrm{~A}$ memiliki nilai defleksi yang paling besar yaitu sebesar $0,0011 \mathrm{~m}$, Untuk sistem suspensi semi aktif dengan arus 0,125 A memiliki nilai defleksi sebesar $9,171 \times 10^{-4} \mathrm{~m}$. Untuk sistem suspensi semi aktif dengan arus 0,25 A memiliki nilai defleksi sebesar 7,5304 x10-4 m. Dan untuk sistem suspensi pasif memiliki nilai defleksi sebesar $9,6740 \times 10^{-4} \mathrm{~m}$. Begitu pula untuk suspensi belakang suspensi didapatkan hasil yang sama dimana sistem suspensi memiliki nilai defleksi yang masih dibawah batas defleksi maksimal yang di diizinkan. Sehingga, dapat dikatakan bahwa suspensi aman terhadap syarat batas defleksi maksimal.

\section{3) Keamanan Kendaraan}

Gambar 12 menunjukkan perbandingan antara respon kemampuan ban menapak jalan antara jenis sistem suspensi pasif, dan sistem semi aktif yang direpresentasikan dengan persentase ban depan menapak jalan. Dimana parameter ini digunakan untuk menyatakan tingkat keamanan kendaraan, semakin besar prosentase ban menapak maka tingkat keamanan kendaraan tersebut juga semakin besar. Pada gambar 12 menunjukkan bahwa minimum dari prosentase ban depan menapak jalan pada frekuensi $0 \mathrm{~Hz}$ sampai $100 \mathrm{~Hz}$ adalah sebesar 50,0167\% dimana menurut Kriteria Keamanan Kendaraan menurut BEISSBARTH Automotive Group untuk prosentase ban menapak antara 40\% - 59\% dikategorikan dalam kondisi cukup baik.

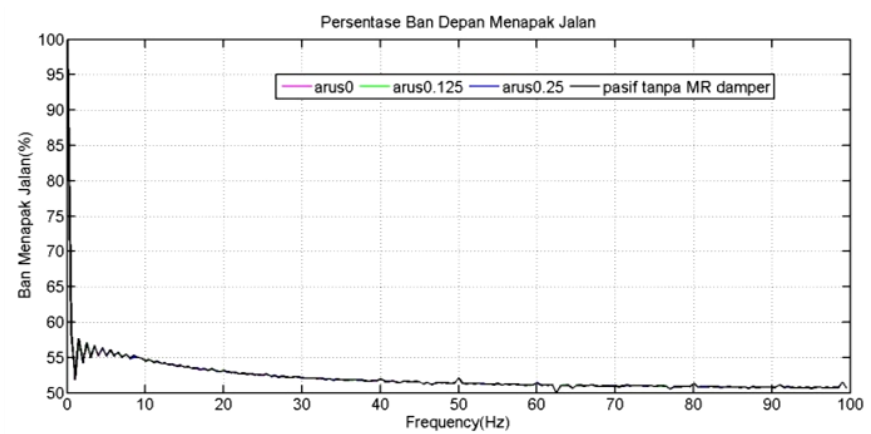

Gambar 12. Persentase Ban Depan Mobil Menapak Jalan

\section{KESIMPULAN}

Berdasarkan hasil simulasi dan analisa terhadap respon gerak mobil multiguna pedesaan dengan model setengah kendaraan (half car) diisimpulkan bahwa :

1. Berdasarkan perhitungan suspensi mobil multiguna pedesaan didapatkan nilai kekakuan pegas helical depan (Ksf) sebesar 56904,57541 N/m, sementara untuk nilai kekakuan pegas helical belakang (Ksr) sebesar $70864,50183 \mathrm{~N} / \mathrm{m}$.

2. Berdasarkan ISO 2631 dan Assesment Diagram of Vibration, didapatkan sistem suspensi semi aktif menghasilkan keyamanan yang baik (RMS $<0,3 \mathrm{~m} / \mathrm{s}^{2}$ ) untuk setiap bagian tubuh pengemudi, penumpang dan alat.

3. Defleksi yang terjadi pada suspensi depan dan belakang berada dibawah batas defleksi maksimal yaitu sebesar 0,1 $\mathrm{m}$ (suspensi depan) dan 0,12 m (suspensi belakang).
4. Berdasarkan Kriteria Keamanan Kendaraan menurut BEISSBARTH Automotive Group prosentase ban menapak dengan perancangan sistem suspensi dikategorikan dalam kondisi cukup baik yaitu pada range 40\%-59\%.

\section{LAMPIRAN}

Tabel 2.

Parameter Peredam Magnetorheological dengan Model Bouc-Wen[3]

\begin{tabular}{|c|c|c|c|}
\hline Parameter & Bouce-Wen & Parameter & Bouce-Wen \\
\hline $\mathrm{k}_{0}$ & $46.9 \mathrm{~N} / \mathrm{cm}$ & $\mathrm{A}$ & 301 \\
\hline $\mathrm{C}_{\mathrm{oa}}$ & $21 \mathrm{~N} \mathrm{~s} / \mathrm{cm}$ & $\gamma$ & $363 \mathrm{sec}^{-2}$ \\
\hline $\mathrm{C}_{\mathrm{ob}}$ & $3.5 \mathrm{~N} \mathrm{~s} / \mathrm{cm} . \mathrm{V}$ & $\beta$ & $363 \mathrm{sec}^{-2}$ \\
\hline$\alpha_{\mathrm{a}}$ & $140 \mathrm{~N} / \mathrm{cm}$ & $\mathrm{n}$ & 2 \\
\hline$\alpha_{\mathrm{b}}$ & $695 \mathrm{~N} / \mathrm{cm} . \mathrm{V}$ & $\eta$ & $190 \mathrm{sec}^{-1}$ \\
\hline
\end{tabular}

Tabel 3.

Data Mobil Multiguna Pedesaan

\begin{tabular}{|c|c|c|c|}
\hline \multicolumn{4}{|c|}{ Spesiinkasi Mobil Multiguna } \\
\hline \multicolumn{4}{|c|}{ Untuk mengangkut pemmpang \& barang } \\
\hline Dimesi Kendaraan & Penumpang & Barang & Satuan \\
\hline Jarak Sumbu roda (L) & 2,59 & 2,59 & m \\
\hline Jarak roda depan ke CG (Lf) & 1,09 & 1,09 & m \\
\hline Jakar roda belakang ke CG (Lx) & 1,5 & 1,5 & III \\
\hline $\begin{array}{c}\text { Jarak Pemumpang Belakang Ke Sumbu Roda } \\
\text { Depan }\end{array}$ & 2,55 & 2,55 & m \\
\hline Jarak Penmmpang Belakang ke CG (Lp) & 1,46 & 1,46 & m \\
\hline Jarak Penmmpang Depan ke CG (a) & 0,29 & 0,29 & m \\
\hline $\begin{array}{c}\text { Jarak Pemumpang Depan ke Sumbu Roda } \\
\text { Depan }\end{array}$ & 0,8 & 0,8 & m \\
\hline Jarak Box ke Sumbu Roda Depan & 2,55 & 2,55 & m \\
\hline Jarak Box ke CG (b) & 1,46 & 1,46 & m \\
\hline Tinggi GG Mobil ke pemukaan tanah (h) & 0,86 & 0,86 & m \\
\hline $\begin{array}{c}\text { Tinggi GG Penumpang Depan ke permukaan } \\
\text { tanah (hs) }\end{array}$ & 0,59 & 0,59 & m \\
\hline $\begin{array}{c}\text { Tinggi GG Pemumpang Belakang ke } \\
\text { permukaan tamah (hp) } \\
\end{array}$ & 1,03 & 0,955 & m \\
\hline Tinggi CG Box ke permukaan tanah (hb) & 1,33 & 1,33 & $\mathbf{m}$ \\
\hline Luas Frontal (Af) & 2,9088 & 2,9088 & $\mathbf{m}^{\wedge} \mathbf{z}$ \\
\hline Koofisien Drag (Cd) & 0,4 & 0,4 & \\
\hline \multicolumn{4}{|l|}{ Berat } \\
\hline Massa Kendaraan Kosong (w) & 8927,1 & 8927,1 & $\mathbf{N}$ \\
\hline Berat penumpang depan (2 orang) (Ws) & 1012,392 & 1012,39 & $\mathbf{N}$ \\
\hline Berat penumpang belakang (6 orang)(Wp) & 3037,176 & 3920 & $\mathbf{N}$ \\
\hline Berat Box (Wb) & 4900 & $\mathbf{N}$ & $\mathbf{N}$ \\
\hline
\end{tabular}

Tabel 4.

Perhitungan Beban yang Diterima Kendaraan Data Kendaraan Mobil Multiguna Pedesaan

\begin{tabular}{|c|c|c|}
\hline \multicolumn{3}{|c|}{ Data Ken daraan Mobil Multiguna Ped esaan } \\
\hline Lf(m) & Penumpang & Barang \\
\hline Lr(m) & $\mathbf{1 , 6 9 2 9 2 9 1 0 1}$ & $\mathbf{1 , 5 8 7 4 3 8 0 6}$ \\
\hline L(m) & $\mathbf{0 , 8 9 7 0 7 0 8 9 9}$ & $\mathbf{1 , 0 0 2 5 6 1 9 4}$ \\
\hline h(m) & $\mathbf{2 , 5 9}$ & $\mathbf{2 , 5 9}$ \\
\hline Berat Maksimal (N) & $\mathbf{1 , 0 0 2 4 1 8 8 2 7}$ & $\mathbf{0 , 9 2 6 9 9 0 0 9}$ \\
\hline Perlambatan Maksimal (m/ $\mathbf{2}$ ) & $\mathbf{1 7 8 7 6 , 6 6 8}$ & $\mathbf{1 5 9 1 7 , 4 9 2}$ \\
\hline Percepatan Maksimal (mi/s $\mathbf{2})$ & $\mathbf{7 , 3 5 7 5}$ & $\mathbf{7 , 3 5 7 5}$ \\
\hline Wf Statis(N) & $\mathbf{3 0 9 5 , 8 7 6 1 8 5}$ & $\mathbf{3 0 8 0 , 7 4 7 4 1}$ \\
\hline Wr Statis(N) & 5842,457815 & 4877,99859 \\
\hline fr (pada jalan aspal) & 0,08 & 0,08 \\
\hline $\boldsymbol{\mu}$ (pada jalan aspal) & 0,75 & 0,75 \\
\hline Hambatan Aerodinamis (N) & 344,6777208 & 344,677721 \\
\hline Hambatan Rolling (N) & 1430,13344 & 1273,39936 \\
\hline Gaya Gesek (N) & 13407,501 & 11938,119 \\
\hline Wf Dinamis Diperlambat (N) & 5690,457541 & 5217,14084 \\
\hline WrDinamis Diperlambat (N) & $\mathbf{3 2 4 7 , 8 7 6 4 5 9}$ & $\mathbf{2 7 4 1 , 6 0 5 1 6}$ \\
\hline Wf Dinamis Dipercepat (N) & $\mathbf{4 3 4 , 5 9 3 7 8 0 6}$ & $\mathbf{8 8 2 , 6 7 1 9 7 1}$ \\
\hline Wr Dinamis Dipercepat (N) & 8503,740219 & $\mathbf{7 0 7 6 , 0 7 4 0 3}$ \\
\hline
\end{tabular}




\section{DAFTAR PUSTAKA}

[1] P. . Ramadhana, "Desain dan Analisa Sistem Suspensi Mobil Produksi Multiguna Pedesaan Dengan Standar Kenyamanan ISO 2631," ITS, 2016.

[2] N. R. Gunawan, "Permodelan dan Studi Karakteristik Sistem Suspensi Semi-Aktif dengan Peredam Magnetorheological,” ITS, 2015.

[3] A. A. . S.J Dyke, B.S., “Acceleration Feedback Control Strategies For Active and Semi-Active Control System: Modeling, Alogarithm Development and Experimental Verification," 1996.

[4] S. . Singiresu, Mechanical Vibration. Singapore: Prentice Hall PTR, 2004. 